\title{
Quantitative Estimation and Use Condition of Learning Materials for Official Ci Poetry in Ming Dynasty*
}

\author{
Xuan Liu \\ School of Language and Literature \\ Harbin Institute of Technology, Weihai \\ Weihai, China 264209
}

\author{
Yan Teng \\ School of Language and Literature \\ Harbin Institute of Technology, Weihai \\ Weihai, China 264209
}

\author{
Jiaoling Jin \\ School of Language and Literature \\ Harbin Institute of Technology, Weihai \\ Weihai, China 264209
}

\begin{abstract}
There were abundant learning materials of $\mathbf{C i}$ poetry in Ming Dynasty, which were mainly concentrated in the palace, central departments, local government offices and imperial vassals' residence. These materials can be read and sold in printed form, promoting the study of people in the Ming Dynasty and improving the creation of $\mathrm{Ci}$ poetry. Due to the dynastic change from Ming Dynasty to Qing Dynasty, it greatly destroyed learning materials of $\mathrm{Ci}$ poetry in Ming Dynasty, and some precious and rare materials were lost. However, the materials with large sales were preserved, which provided the literature basis for the revival of Ci poems in the Qing Dynasty.
\end{abstract}

Keywords—Ming Dynasty; Ci poetry; learning materials

\section{INTRODUCTION}

The prosperity of novels and operas in the Ming Dynasty was quite strange to the Ci poetry of Song Dynasty in full flush. Specifically speaking, there were fewer and fewer $\mathrm{Ci}$ writers in literary circles, and there were few books on Ci Poetry on the market. In the past, Song $\mathrm{Ci}$ could be sung, but even scholars in the Ming Dynasty did not know how to sing according to the music. In the middle and late Ming Dynasty, the writing of $\mathrm{Ci}$ gradually became fashionable, and more and more people were interested in $\mathrm{Ci}$, which required some learning materials to guide.

There are five kinds of learning materials: first, it is $\mathrm{Ci}$ collection. Through reading and imitating the previous $\mathrm{Ci}$ collections, learners achieve intuitive learning. For example, Xin Qiji's Ci collection was very popular at that time. Second, it is $\mathrm{Ci}$ selection. Booksellers picked out some famous $\mathrm{Ci}$ poems, so that learners could focus on one type of work. Third, it is comment on $\mathrm{Ci}$, that is, the evaluation of $\mathrm{Ci}$. Through

*Fund: This paper is stage results of "Chinese major's graduation project in information management system development" (YYWX201704), "the course teaching material construction research on Korean Practical Style Writing" (YYWX201710). reading these comments, learners learned what kind of $\mathrm{Ci}$ poems the authorities think were good works and what kind of $\mathrm{Ci}$ poems were not good, so as to establish their own evaluation criteria. Fourth, it is score of Ci. The Song Dynasty also had $\mathrm{Ci}$ scores. Those were music scores, used to sing. But scholars of the Ming Dynasty have been unable to understand such scores, so they compiled some more easily understandable metrical scores. Beginners could complete a $\mathrm{Ci}$ poem according to the tone and format marked by the score. Fifth, it is $\mathrm{Ci}$ rhyme. Both poem and $\mathrm{Ci}$ need rhymes. And these rhymes can be imitated to create other $\mathrm{Ci}$ poems.

Some of these learning materials are printed and sold by booksellers and can be easily purchased. However, some materials have not been retained. Today we have no idea what materials booksellers printed. In addition, the Ming Dynasty also collected and printed some learning materials, and these materials are preserved. Next we will estimate the relevant situation and understand the use condition.

\section{HAVING A CERTAIN NUMBER OF BOOKS IN THE}

IMPERIAL PALACE, IMPERIAL DEPARTMENTS AND LOCAL

\section{GOVERNMENT OFFICES}

According to The Booklist of Wenyuan Pavilion (the first edition of a series of books) compiled by Yang Shiqi and others in the 6th Zhengtong Year (1441), the palace Ci-poetry literature is mainly stored in two bookcases marked with the Chinese word "月". The collections of $\mathrm{Ci}^{1}$ include Mr. Yuan's Long and Short Sentences, Jiaxuan's Long and Short Sentences, Huaihai Hermit's Long and Short Sentences, Jianquan Poetry, Caotang Poetry, Xin Jiaxuan's Ci, Teng Yuxiao's Ci, Qin Qu

For the judgment of the collection of Ci poems, refer to Full Collection of Song Ci, Full Collection of Jin Ci, Full Collection of Ming Ci, Rao Zongyi's Research on Ci Collections, Wang Zhaopeng and Liu Zunming's Song Ci Dictionary, Tang Guizhang's Research on Song Ci Version and Wang Hong's Encyclopedia Dictionary of Tang Ci and Song Ci. 
Wai Pian, Jian Zhai Ci, Yan Bo Yu Yin Ci, Yangchun Baixue, Liu Gong's Music Movement, Poetry of Xu Dongji, Poems of Various Schools, Ci of Meiyuan, Banquet Ci of Zhujia Yan, Songs of Baishi Taoist, Qingjiang Fishing Poems and Li Weigong's Wang Jiang Nan. In addition, the Ancient and Modern Tongji Library and the Imperial Archive have the original and duplicate of Yongle Encyclopedia, which is like a dictionary. Although there is no $\mathrm{Ci}$ collection, there are many poems in it.

According to $\mathrm{Fu}$ Xuancong's General History of Chinese Book Collection, the imperial court had a system for the collection of books by local governments, and quoted Qiu Jun's Supplement to the Exposition of the Great Learning as evidence. The author looked through the Supplement to the Exposition of the Great Learning and found that $\mathrm{Mr}$. Fu has made a mistake in his quotation. Now make a copy of Jiajing edition: "Today's city government has maps and geographical books. Copies are collected in the school. The Ministry of Rites has collected geographical books of the country, and stored in the ministry. The imperial court also issued four books and five classics to local schools, and school principals are in charge of them. It is also an extension of ancient educational ideas. From the above statement, we can understand how ancient people valued geography books. In the Tang Dynasty, the government had the Ministry of War, which consisted of four departments, one of which was the department of regional military, and we continued this system in the Ming Dynasty. The department of regional military manages frontier defense and military affairs, and they have border maps and geography books." However, there are no official bibliographies in this part of the collection, and few materials have been circulated to today. Academic circles generally quote Zhou Hongzu's Ancient and Modern Book List. The book list records all books collected in the six government departments and local governments during the Wanli period. There are 185 families and 2710 kinds of books ${ }^{2}$. Today's scholars, on this basis, combine other materials and make supplements. For example, add 8 books to the six books in $\mathrm{Fu}$ Xuancong's General History of Chinese Book Collections; Liu Jiaojiao compiled the Book List of Local Government in the Ming Dynasty according to Wang Chongmin's Summary of Rare Ancient Chinese Books, Taiwan National Library's Draft of Rare Book Records in National Library, Du Xinfu's Inscription Catalogue of Ming Dynasty, Shen Jin's Rare Chinese Book Records in Harvard Yanjing Library of Harvard University in the United States and Rare Ancient Chinese Book Record in the East Asian Library of the University of California, Berkeley, compiled by the East Asian Library of the University of California, Berkeley. Of course, the existing materials cannot reproduce all the books collected by the Ming Dynasty's academies and local governments, but we can infer the collection of $\mathrm{Ci}$ poetry books from them.

Ancient and Modern Book List perfectly explains Qiu Jun's statement that different functional organs have different kinds

There are many editions of Ancient and Modern Book List, such as editions of Ye Dehui and Huang Jiashan. The contents are not the same. Chen Qinghui's Textual Research on Ancient and Modern Book List (No. 4 of Documents 2007) has compared editions of Ye and Huang and obtained the above figures, which is more credible. of books. The Ministry of Rites mainly collected books such as Jiubian Tushuo. The Court of Censors and the Imperial Academies of Beijing and Nanjing collected various kinds of books. The Imperial Academy of Beijing ever inscribed and printed Qin Guan's Huaihai Collection. The whole book contains three volumes of long and short sentences. None of the other literatures has been studied.

Part of the books collected by local governments was bestowed by the court. In addition, some were imperial edicts and edification books. Ancient and Modern Book List records: Nanzhili Suzhou Prefecture printed Huajian Collection and Fubu Collection ${ }^{3}$; Songjiang Prefecture and Huizhou Prefecture printed Caotang Poetry; Chizhou Prefecture printed Cui Shihuan's Collection; Yangzhou Prefecture printed Caotang Poetry and Guangde Prefecture printed Bamboo Branch Ci; Zhejiang Ancha Department printed Bamboo Branch Ci; Chuzhou Prefecture printed Xieqing Collection; Linjiang Prefecture printed Caotang Poetry; Huguang Wuchang Prefecture printed Illustration of Poetry and Shandong Buzheng Department printed Huaihai Collection.

List of Local Official Engraving Books of Ming Dynasty records: Beizhili has printed Collection of Taishi Chengyibo Liu Wencheng, 18 volumes; Baoding Prefecture printed Li Weigong's Wang Jiang Nan, one volume; Yangzhou Prefecture printed Huaihai Collection, 40 volumes in the 24th Jiajing Year (1545), six volumes of post-collection and three volumes of long and short sentences ${ }^{4}$, and printed Huaihai Collection, 40 volumes, six volumes of post-collection and three volumes of long and short sentences 5 again in the 46th Wanli Year (1618). In the sixth year of Zhejiang Chenghua (1470), it printed Literature Collection of Chengyibo Liu, 20 volumes, and Collection of Taishi Chengyibo Liu Wencheng, 20 volumes, in the sixth Longqing Year (1572). Chuzhou Prefecture ever printed Literature Collection of Chengyibo Liu, 20 volumes. All Collection of Liu Ji mentioned above contained Xieqing Collection. Jiangxi Fansi Department ever printed Full Collection of Ouyang Wenzhong, 135 volumes, and there are 3 volumes of Ci. Jiangxi Buzheng Department ever printed Full Collection of Su Wenzhong, 110 volumes, and there was one volume of chronicle which has $\mathrm{Ci}$. Ji'an Prefecture printed Full Collection of Ouyang Wenzhong, 135 volumes, and five attachments and one chronicle, for four times, respectively in the 5th Tianshun Year (1461), the 7th Zhengde Year (1512), the 16th Jiajing Year (1537) and the 39th Jiajing Year (1560). In the 4th Chenghua Year (1468), it printed Full Collection of Su Wenzhong, 100 volumes, and one volume of chronicle. Shandong has printed Huaihai Collection, 40 volumes, six volumes of the post-collection, and three volumes of long and short sentences, and Collection of

Ancient and Modern Book List doesn't record the author of Fubu Collection, and several writers named their works as it. For example, among the six volumes of the book written by Zhao Yuyuan of Song Dynasty, there is one volume of long and short sentences. Collections of Zhu Tong and Liu Ji of Ming Dynasty have no Ci.

According to List of Local Official Engraving Books of Ming Dynasty, it was not "the 23th Jiajing Year". It should be "the $24^{\text {th }}$ Jiajing Year", and the author has miswritten it.

According to List of Local Official Engraving Books of Ming Dynasty, it was not "the 46th Jiajing Year". It should be "the $46^{\text {th }}$ Wanli Year", and the author has miswritten it. 
Mr. Hou Shan, 30 volumes, and there was Ci. Ningzhou Prefecture printed $\mathrm{Ci}$ of Huang Yuzhang, one volume, Literature Collection of Huang Yuzhang, 30 volumes, and 14 volumes of external collection, 20 volumes of individual works, one volume of $\mathrm{Ci}$, two volumes of Chidu and 30 volumes of chronicles.

According to the above statistics, the literature on $\mathrm{Ci}$ poems collected by the imperial court, departments and local governments is popular books on $\mathrm{Ci}$ poems, such as, Huajian Collection and Caotang Collection, and $\mathrm{Ci}$ collection attached in Xiangxian Collection.

\section{THE LITERATURE OF CI POETRY COLLECTED IN THE VASSAL RESIDENCE OF MING DYNASTY}

In Zhang Xiaoshan's Yuefu Preface, Li Kaixian said: “on the founding of the country, Zhu Yuanzhang gave his son 1,700 literary books." "The literary books" here were drama, not $\mathrm{Ci}$. This statement is not accurate, Peng Qiuxi discussed in 'Hongwu Ciqu' and Significance of its Quxue History. But the emperors of Ming Dynasty did give books to all the princes. Not only Zhu Yuanzhang did so. Cao Zhi, in the Research on Ming Emperors Giving Books to Princes, concluded: from the beginning of Zhu Yuanzhang, until the Ming Emperor Shenzong, the emperors of Ming Dynasty have continued the activities of giving books to princes. In this way, it is normal for the princes of the Ming Dynasty to have many books. Qian Qianyi said, "people who have the most books in the world today are these princes. The books collected in the residences of Vassal Zhou and Vassal Ning are as many as the emperors."

"Vassal Zhou" refered to Zhu Mujie, who once gave a lecture in the west of Shuizhu Residence. Scholars called him "Mr. Xiting". Vassal Ning was Zhu Mouhan, the 7th from Ningxian Prince, who styled himself Yuyi.

Most of the imperial palaces of the Ming Dynasty had bibliographies, which were not many to be seen today. But the bibliographies remained so that we could see the grand occasions of the time. Judging from Zhu Mujie's Family Collection Art and Literature Self-Records of Wanjuan Hall, his books are mainly purchased from Ge family in Jiangdu and the Li family in Zhangqiu. He had five book studies, and the books in it were arranged in circles. The method of the Tang Dynasty was imitated to divide into four categories, which were represented by labels of various colors. These books are very, very valuable, many, very rare. By reading this bibliography, the author finds several collections of $\mathrm{Ci}$ in this essay: “Zhao Chongyou's Huajian Collection, Xin Qiji's Long and Short Sentences of Jiaxuan, Zhang Yan's Illustration of Poetry, Gu Congjing's Caotang Poetry, Huang Tingjian's Poetry of Huang Yuzhang, Yunlinqing Appreciation, and Caotang Poetry of Famous Confucian." The editions of $\mathrm{Ci}$ books are very good. For example, generally there are two, three, four, five, six, and nine volumes of Caotang Poetry, and three volumes of Caotang Poetry of Famous Confucian. One volume of it has not yet been seen. But Caotang Poetry of Famous Confucian in the residence of Prince Zhu is of one volume, which is the only one I have seen.
IV. ThE DAMAgE OF THE DYNASTY CHANGE FROM Ming DYNASTY TO QING DYNASTY TO THE LEARNING MATERIALS OF CI POETRY

In the 17th Chongzhen Year (1644), Li Zicheng burned the emperor's palace when he left Beijing. Wenyuan Pavilion was burned down, and all the books were burned down, including the study materials of Ci-poetry mentioned earlier. People at that time were very sad, saying that Li Zicheng had done the worst. Fortunately, Yongle Encyclopedia had its original and duplicate copies. The original copy had been destroyed by Li Zicheng's fire in the late Ming Dynasty. The duplicate copy was stored in the Imperial Archive. There was no wood in the whole warehouse. It was built of stone and metal. It was very flame-retardant, so it avoided the fire. In the twelfth year of Shunzhi (1655), Zhang Nenglin entered the Imperial Archive for inspection and saw Yongle Encyclopedia. He described it in detail: "These books are very rare. They are placed on metal bookshelves. There are dozens of bookshelves. There are many books wrapped in yellow baggage and there are ten million catalogues on the shelves. The contents include astronomy, geography, customs and characters, emperors, policies, military affairs, agriculture, music, and even grass, wood, birds, animals, insects, fish and so on. Everything is written in great detail. These books are called Yongle Encyclopedia." Through Zhang Nenglin's words, we knew that Yongle Encyclopedia was well preserved. In the forty-third year of Kangxi (1704), Cha Shenxing and others compiled Pei Wen Yun Fu and also saw Yongle Encyclopedia, and said that the number of volumes is really many, and the books had not been destroyed.

In the late Ming and early Qing Dynasties, many of the highness of the Ming Dynasty died, and their property was confiscated, and their books were lost. Vassal Zhou and Vassal Ning were the only ones we know the whereabouts. Vassal Zhou's books were washed away by the flood. Vassal Ning's books were burnt down and none piece of paper was left behind. Some of highness's books were scattered among the folk. And some of the surviving books have entered the market again for sale.

\section{CONCLUSION}

Due to the dynasty change from Ming to Qing Dynasty, many learning materials of $\mathrm{Ci}$ were destroyed. Generally speaking, the fewer printed materials, the lower the ability to resist destruction. So many books with only one book disappeared in the war, which was a great loss in the history of Ci. Fortunately, the study materials of the Ming Dynasty were very popular. Mao Jin once said that the sales of Caotang Poetry were very high at that time, and almost every family had it. Although this statement is exaggerated, it also reflects the popularity of it at that time to a certain extent. Even if these words are damaged during the war, there are other copies to be added. Judging from the statistics of Zhu Yizun and other people in the early Qing Dynasty, after the war of the dynasty change, there are still about several hundred kinds of $\mathrm{Ci}$ collection left. And after the war, the books that had been kept in the imperial palace were also on the market, which was more conducive to the study of $\mathrm{Ci}$. In short, the extensive dissemination of learning materials is helpful to the study and creation of $\mathrm{Ci}$ poets in the Ming Dynasty. In the early Qing 
Dynasty, the creation of $\mathrm{Ci}$ poetry was very prosperous, which was closely related to these learning materials.

\section{REFERENCES}

[1] Fu Xuancong. General History of Chinese Collections, Part 6, Collections of the Ming Dynasty, Ningbo Publishing House, 2001, P. 546.

[2] Qiu Jun. Supplement to the Exposition of the Great Learning, Volume 94, Jiajing Jicheng printed edition.

[3] Lv Lihan. Textual Research on Sources of Different Editions of Liu Ji's Collection, the collection collected in Beijing Library has Xieqing Collection. Literature Relics, Issue 2, 2000.

[4] Qian Qianyi. Book Collection Record of Mr. Huang's Qianqing Pavilion, Collection of Muzhai Youxue, Volume 26, Shanghai Ancient Books Publishing House, 1994, P. 995.

[5] Zhang Tingyu. Ming History, 116 volumes, Collection of Various Editions of Ming History.

[6] Zhang Sheng. Circulation of the Original Edition of Yongle Encyclopedia, Library Construction, Issue 1, 2003.

[7] Zhang Nenglin. Secretaries of Imperial Archive, Xishan Collection, Volume 3, cited from Gao Shuwei's A Forgotten History of Collection about Yongle Encyclopedia, Pengpai News, August 19, 2017. 